\title{
PENGOLAHAN JAHE MENJADI SERBUK INSTAN DAN PEMBUATAN NUGGET BERBAHAN DASAR TEMPE SEBAGAI UPAYA PEMBERDAYAAN KAUM WANITA UNTUK MENINGKATKAN PEREKONOMIAN MASYARAKAT DESA KARANGGONDANG, PABELAN, SEMARANG
}

\author{
Tri Budiyanto dan Mahasiswa KKN Reguler 61 Divisi I.D TA 2016/2017 \\ Universitas Ahmad Dahlan Yogyakarta
}

\begin{abstract}
Abstrak
Permasalahan yang ditemukan terkait dengan perekonomian di Desa Karanggondang, Kecamatan Pabelan adalah kurang terciptanya ekonomi kreatif dengan memperhatikan potensi alam, tidak adanya program pelatihan dari pemerintah dalam pengembangan ekonomi kreatif serta kurangnya pengetahuan kaum wanita dalam memanfaatkan keterampilan yang dimiliki, oleh karena itu KKN UAD menyelenggarakan kegiatan penyuluhan dan pelatihan sebagai upaya pemberdayaan kaum wanita untuk meningkatkan perekonomian masyarakat desa. Dampak dari kegiatan KKN di lokasi ini adalah : 1) terwujudnya kesadaran akan pentingnya berwirausaha untuk meningkatkan perekonomian keluarga pada khususnya dan masyarakat pada umumnya 2) memberikan pengetahuan mengenai pemanfaatan salah satu potensi yang ada di Desa Karanggondang yaitu jahe 3) kaum wanita di Desa Karanggondang paham dan terampil dalam merintis usaha pembuatan serbuk jahe instan dan nugget tempe.
\end{abstract}

Kata kunsi; pengolahan jahe, instan, pemberdayaan wanita.

\begin{abstract}
The problems found to be associated with the economy in Karanggondang Village, District Pabelan is the less creation of creative economy regarded to the potential of natural resources. There is also no training program from the government that aims to develop creative economy. Another problem is the lack knowledge of the women to use her skill. Therefore the Student Community Service Regular UAD held counseling and training programs as the effort to empower women, so the economy of village community will be better. The effect of the Community Service activities are: 1) create awareness of the importance of entrepreneurship to improve the economy of the family in particular and society in general, 2) provide knowledge about the use one of the potential existing in the village Karanggondang, ginger 3) women in the village Karanggondang understand and skillful in pioneering the business of making instant ginger powder and tempeh nuggets.
\end{abstract}

Keywords: ginger processing, instant, empowering women. 
Diterbitkan oleh Lembaga Pengabdian kepada Masyarakat

Universitas Ahmad Dahlan Yogyakarta

\section{A. PENDAHULUAN}

Desa Karanggondang merupakan salah satu dari 17 Desa di Kecamatan Pabelan Kabupaten Semarang, secara geografis sangat mendukung menjadi penghubung antar desa karena berada ditengah - tengah Kecamatan Pabelan yang dilalui oleh desa - desa di Kecamatan Pabelan. Hingga sekarang ini terutama di sektor ekonomi, perkembangan pembangunan di desa Karanggondang mengalami banyak kendala karena mereka hanya mampu menyumbangkan tenaganya dan untuk bantuan materi sangatlah rendah. Permasalahan kemiskinan juga masih menyisakan $75 \%$ dari penduduk Desa Karanggondang yang masih mengandalkan pemenuhan kebutuhan dengan menjadi buruh tani .

Berbagai permasalahan yang ditemukan terkait dengan perekonomian di Desa Karanggondang, Kecamatan Pabelan adalah: 1) kurang terciptanya ekonomi kreatif dengan memperhatikan potensi alam 2) tidak adanya program pelatihan dari pemerintah dalam pengembangan ekonomi kreatif 3) kurangnya pengetahuan kaum wanita dalam memanfaatkan keterampilan yang dimiliki.

Pemberdayaan wanita sendiri merupakan suatu proses yang memungkinkan setiap wanita Indonesia mampu memenuhi pilihannya sendiri secara bijaksana. Cara atau strategi yang paling rasional untuk membebaskan kaum wanita dari kungkungan kebodohan, kemiskinan, dan keterbelakangan adalah memberdayakan mereka, baik dari dimensi ekonomi, pendidikan, kesehatan, dan lain sebagainya. Kaum ibu dapat ikut serta membangun keluarga, lingkungan serta mengembangkan sifat dan jiwa kewirausahaan dengan ikut serta dalam gerakan pemberdayaan ekonomi keluarga (Ruslan, 2014).

\section{B. METODE PELAKSANAAN}

Untuk mewujudkan tujuan yang diharapkan, program KKN di lokasi Desa Karanggondang, Kecamatan Pabelan, Kabupaten Semarang, Provinsi Jawa Tengah dilakukan dengan pemberdayaan masyarakat melalui pembekalan pengetahuan tentang pentingnya wirausaha, memberikan pelatihan pembuatan jahe instan dan nugget tempe serta pendampingan langsung kepada kaum wanita dalam pembuatan produk tersebut.

Tabel 1. Metode, Kegiatan, JKEM, dan keterlibatan mahasiswa

\begin{tabular}{|l|l|l|l|l|}
\hline No & Metode & Kegiatan & JKEM & $\begin{array}{l}\text { mahasiswa } \\
\text { yang terlibat }\end{array}$ \\
\hline 1. & Pendidikan & $\begin{array}{l}\text { Penyuluhan mengenai cara } \\
\text { pembuatan jahe instan }\end{array}$ & $3 \times 100$ ’” & unit \\
\hline 2 & Pelatihan & $\begin{array}{l}\text { Menyelenggarakan } \\
\text { pelatihan pembuatan Jahe } \\
\text { Instan }\end{array}$ & $3 \times 200 ”$ & unit \\
\hline 3. & Pelatihan & $\begin{array}{l}\text { Menyelenggarakan } \\
\text { pelatihan pembuatan nugget } \\
\text { berbahan dasar tempe }\end{array}$ & $3 \times 200 ”$ & unit \\
\hline
\end{tabular}




\section{HASIL, PEMBAHASAN DAN DAMPAK}

\section{Profil Desa}

Desa Karanggondang adalah salah satu dari 17 Desa di Kecamatan Pabelan Kabupaten Semarang, secara geografis sangat mendukung menjadi penghubung antar desa karena berada ditengah - tengah Kecamatan Pabelan yang dilalui oleh desa - desa di Kecamatan Pabelan . Desa Karanggondang Kecamatan Pabelan Kabupaten Semarang keseluruhan luasnya sebesar 235,5 Ha .Secara administratif berada di garis perlintasan antara Kecamatan Pabelan dan Kecamatan Suruh. Luas secara keseluruhan sebesar 235,5 ha atau sekitar $15 \%$ dari luas Kecamatan Pabelan , secara administratif terdiri 3 Dusun, 3 Rukun Warga , 15 Rukun Tetangga. Penduduk Karanggondang pada akhir tahun 2015 sebanyak 1711 jiwa dan pada akhir tahun 2015 menurut data dari data SMARD Dinas Catatan Sipil Kabupaten Semarang . Jumlah jiwa jika dilihat di wilayah Desa Karanggondang stabil untuk setiap tahunannya , ini dilihat dari jumlah Lahir , mati , pindah dan datang. Sementara bila dilihat sex ratio penduduk tahun 2015 diketahui bahwa perbandingan penduduk laki-laki dengan perempuan sebesar $49.2 \%$ dan $50.8 \%$, artinya jumlah penduduk perempuan lebih besar 0,002 \% dibanding laki-laki. Mata pencaharian utama penduduk dari 2016 masih didominasi dari sektor pertanian,yang terdiri dari petani dan buruh tani , selain bekerja di sektor industri perdagangan, dan jasa . Persentase mata pencaharian penduduk Kabupaten Semarang terlihat pada gambar 1.

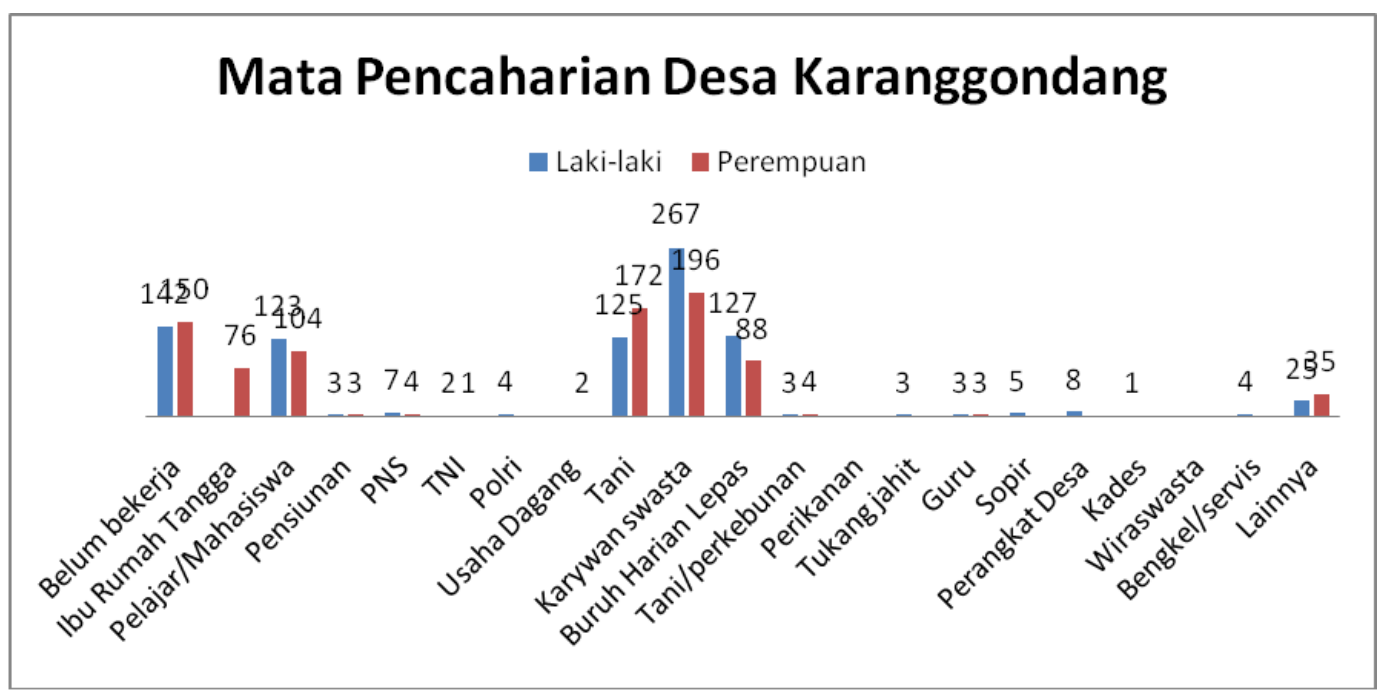

Gambar 1. Diagram Mata Pencaharian Penduduk Desa Karanggondang Kecamatan Pabelan Kabupaten Semarang Berdasarkan Lapangan Usaha Tahun 2016

Untuk dunia wirausaha, masyarakat Desa Karanggondang masih dapat dikategorikan berada pada level kecil dikarenakan dari 1668 jumlah penduduk Desa Karanggondang hanya ada 2 orang yang mata pencahariannya sebagai wirausaha. Oleh karena itu, perlu adanya pemberdayaan masyarakat khususnya untuk kaum wanita dalam bidang ekonomi yaitu menumbuhkan jiwa wirausaha melalui penyuluhan dan pelatihan. 
Diterbitkan oleh Lembaga Pengabdian kepada Masyarakat

Universitas Ahmad Dahlan Yogyakarta

\section{Aktivitas KKN terkait Pemberdayaan}

Berdasarkan data jenis pekerjan serta potensi yang ada di desa Karanggondang, aktivitas mahasiswa KKN sangat tepat memberikan pelatihan guna menumbuhkan jiwa kewirausahawan untuk meningkatkan perekonomian masyarakat. Pemberdayaan yang diberikan kepada kaum wanita dalam bentuk pelatihan pengolahan jahe menjadi serbuk instan dan pembuatan nugget berbahan dasar tempe. Aktivitas kedua pelatihan tersebut dapat dilihat pada gambar 2 dan 3.

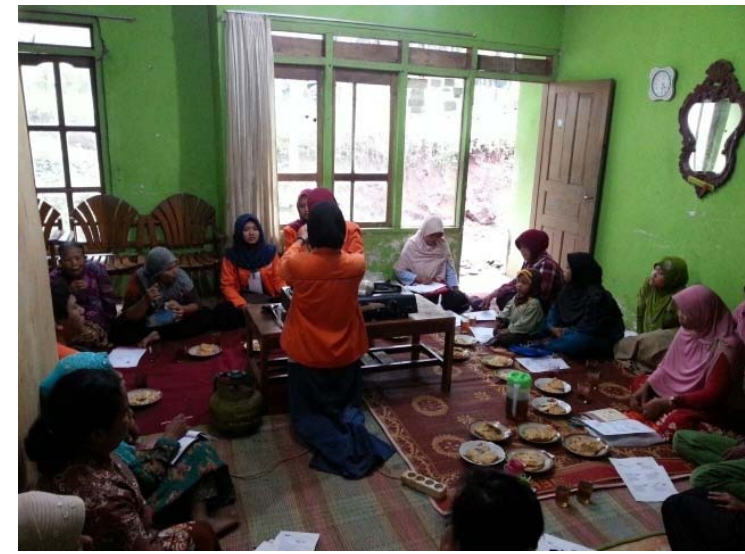

Gambar 2. Pelatihan membuat serbuk jahe instan

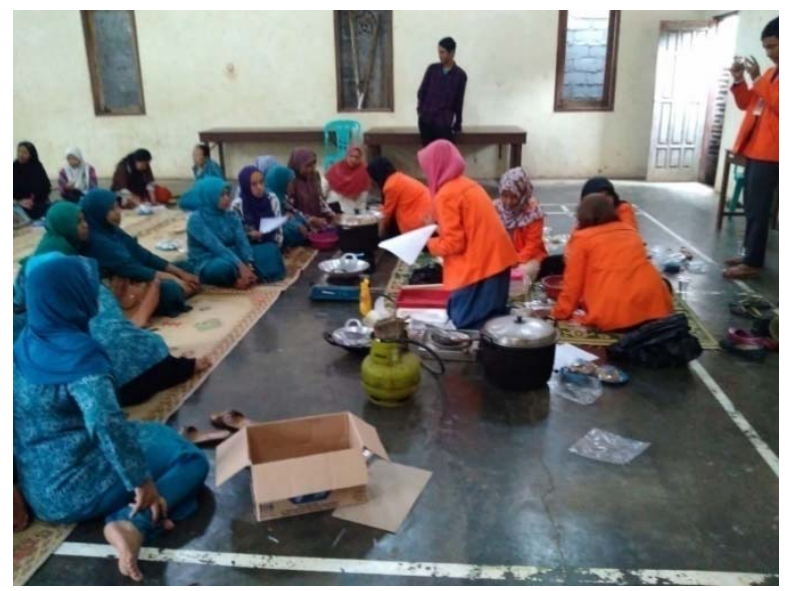

Gambar 3. Pelatihan membuat nugget tempe

Dari gambar 2 dan 3 menunjukkan penerapan program KKN dalam bidang pemberdayaan untuk kaum wanita di Desa Karanggondang dapat terlaksana dengan baik dan didukung partisipasi masyarakat yang tinggi. Dampak dari kegiatan KKN di lokasi ini adalah : 1) terwujudnya kesadaran akan pentingnya berwirausaha untuk meningkatkan perekonomian keluarga pada khususnya dan masyarakat pada umumnya 2) memberikan pengetahuan mengenai pemanfaatan salah satu potensi yang ada di Desa Karanggondang yaitu jahe 3) kaum wanita di Desa Karanggondang paham dan terampil dalam merintis usaha pembuatan serbuk jahe instan dan nugget tempe. 


\section{KESIMPULAN}

Kegiatan KKN UAD dalam memberdayakan kaum wanita bidang ekonomi di Desa karanggondang telah berjalan dengan baik dan sesuai rencana program kerja.

\section{DAFTAR PUSTAKA}

Ruslan, Murniati. 2014. Pemberdayaan Wanita Dalam Dimensi Pembangunan Berbasis Gender. 2 (1): 79-96 